\title{
Do all paths lead to Rome? Technology and Market Orientation influence on the growth of new technology-based firms
}

\author{
Ferran Giones, Francesc Miralles \\ La Salle - Universitat Ramon Llull \\ Barcelona,Spain \\ Fgiones@salleurl.edu
}

\author{
Marc König, Guido Baltes \\ HTWG Konstanz \\ Konstanz, Germany \\ $\underline{\text { Koenig@bwcon.de }}$
}

\begin{abstract}
Technology commercialization is described as the most dreadful challenge for technology-based entrepreneurs. The scarcity of resources and limited managerial experience make it a daunting task, putting in danger the whole firm emergence.

Prior research has often build upon the resource-based view to propose that the new firms' performance is dependent on their initial resource endowments and configurations. Nevertheless, little is known on how the early-stage decisions of the entrepreneur might influence on the growth of the firm. Scholars have suggested that both technology and market orientation actions could influence the performance and growth of firms in this context; nevertheless, there is limited empirical evidence of the influence of these different orientations in the context of new technology-based firms (NTBFs).
\end{abstract}

In this study we propose to explore the influence of technology and demand creation actions adopting a demand-side view. We use a longitudinal study on a panel dataset (2004-2007) with 249 U.S. new high-technology firms to test our hypothesis. The results point towards a rather limited influence of initial resource configurations, as well as an unexpected influence of market and technology orientation in the growth dimensions of an NTBF. The research holds implications for the management of new technology-based firms and for those interested in supporting the development of technology entrepreneurship.

Keywords - technology entrepreneurship, market orientation, demand-side view, growth.

\section{I.INTRODUCTION}

The emergence of technology entrepreneurship as a phenomenon has attracted the interest of policy makers and researchers alike. In both contexts we have found unexpected difficulties, while policy makers have struggled to find the right levers to promote successful technology-based entrepreneurs [1], [2]; academic scholars have found it difficult to define the construct and advance in its understanding [3][5]. The underappreciated complex nature of technological innovations in the entrepreneurial context has been suggested as one of the potential causes that explains the meager returns of most policy and research initiatives [6].
A more detailed description of the nuisances that technology introduces in the entrepreneurship process point towards the difficulties in giving attention to both technology and market development [7]. Similar to the duality that innovative companies face when deciding between technologypush or demand-pull strategies [8], technology entrepreneurs face this challenge with additional constrains and limitations.

We often see cases of entrepreneurs that started their new ventures endowed with strong technological resources (including patents and technological knowledge) but that could not come out with a valuable technological application. Similarly, we can describe cases where a close focus to the market helped to gain service-based revenues, but also limited the growth of the firm, delaying the launch of a scalable market offering.

Prior research has proposed to study the influence of initial resource configurations in the future performance of new venture performance [9], [10], in most cases, assuming the preexistence of an homogeneous market demand for the products or services of the new venture [11]. Nevertheless, little is known on the value of resources in contexts, such as technology entrepreneurship, where market demand is not well defined and heterogeneous [12].

This paper starts with a literature review on technology entrepreneurship as an academic research construct, it follows with a description on the different perspectives used to explain the early-stages development of new technology-based ventures. Then, an extended theoretical framework is proposed, including insights from demand-side view perspectives such as the function of technology and market orientation in the value creation process. The paper follows with a description of the method and data used to test the set of hypotheses, an explanation of the data analysis and results. We wrap up with a discussion of the findings, limitations and conclusions. 


\section{LITERATURE REVIEW}

\section{A. Technolgy Entrepreneurship}

The definition of technology entrepreneurship and its specific characteristics has attracted researcher's attention. Scholars agree to highlight that one of the specificities is that it involves entrepreneurial opportunities that derive from advances in scientific or engineering research [5]. Additionally, it is suggested that a singular element of technology entrepreneurship is the iterative nature of the process (as a sequence of activities) and the co-production of outputs with internal and external stakeholders [3].

The iterative and co-creation nature of technology entrepreneurship is described as a mechanism to mitigate the perception of uncertainty that dealing with new research advances and unclear market demands puts in the entrepreneurial venture [13]-[15]. On the one hand, scholars argue that technology entrepreneurship requires "specialized human resources" [3, p. 10], be it prior entrepreneurial experience, or specific knowledge on the technology at hand or the potential market. On the other, it requires the ability to manage the joint exploration and exploitation of the opportunity, or in other words, investing and executing at the same time [3].

Thus, the elements that build the definition of the technology entrepreneurship as a phenomenon, offer some clues for a theoretical framework to explore the factors that could influence the behavior and outcomes of new firms in this context. Using the term new technology-based firms (NTBFs) we identify the new ventures that are driven by the technology entrepreneurship process.

\section{B. Resource and Demand-side view}

Entrepreneurship research has traditionally relied in the resource-based view to support the exploration of factors that could influence the performance of new ventures [16]. Building on the expectation that we can explain part of the venture performance on the unique, heterogeneous, nontransferable resources that the new venture has [17]. In the context of technology entrepreneurship, this leaves us with the expectation that the venture development success can be traced to the first component of the definition: "specialized human capital" [3, p. 10]. Nevertheless, this would only help to understand those situations where experienced or well trained professionals lead successfully the growth of a new venture. Providing little understanding on situations where novice entrepreneurs, or new entrants in a market or industry have been able to successfully grow their venture. Thus, we would expect the presence of additional elements or factors in the early-stage growth of new ventures.

Scholars have suggested that expecting that initial configurations of resources could provide with a plausible explanation of the new venture development, actually introduces unneeded constrains on our understanding of phenomena such as technology entrepreneurship [18]. The embedded assumption in the resource-based view perspective is that resources are heterogeneous, but that the market for firms' products is homogeneous (in demand preferences); this contrasts with what we observe in dynamic technology markets: (1) unclear perceived value (not externally fixed) or application for the technological product or service, (2) changing incipient demand, where customers latent needs are activated through iterative activities with the market [19]

As a result, our expectation is that the second part of the definition describing the "ability to manage the joint exploration and exploitation" of the opportunity [3], could provide insights on the value creation and value capture in technology entrepreneurship. The suggestion that part of the outcomes of the process will be dependent on the ability to explore and exploit, requires a theoretical view that provides a linkage between exploration and value creation, as well as to the exploitation and value capture [4], [20]. The demand-side view proposes that we can explain the growth of new firms by observing the influence of actions that work as triggers of the willingness to pay by the customers (also defined as value creation [12]). Prior research in complex goods (such as technology-based products and service) suggests that in this type of markets, we could expect that instead of resources, the observable actions (and its symbolic value) could provide clues of the drivers successful market creation and venture growth [21].

Therefore, we propose a theoretical framework that aims to combine, as in the definition of technology entrepreneurship, "resource" like factors, but that also includes sets of actions (described as new venture's orientation) that can be "demandside" like factors.

\section{Hypothesis development}

\section{1) Founder's Human Capital}

In a context where the new venture is often endowed with limited tangible resources, the knowledge and skills of the founders can become a key factor on the future success of the firm. The study of the linkage between human capital and firm performance has been addressed in prior research; suggesting for example the influence of prior knowledge in the identification of entrepreneurial opportunities [22], or the positive influence of holding knowledge on the market and customer needs in the same or a similar industry [23].

Nevertheless, we have limited evidences on NTBFs' setting, where potential market novelty factor might make prior knowledge outdated in relation to actual needs and customer problems; or where prior experience might actually constrain the ability of the entrepreneur to learn in the new context [24]. At this point is relevant to identify different sources of founder's human capital, with the intention to "disentangle" [25, p. 801] the effects generated by overall work experience, from those generated by prior entrepreneurial experience.

In this sense, years of work experience could be an important element in the founder's human capital. It would provide managerial experience in the early stages, and much needed knowledge on how to operate a new business [23]. In addition, years of work experience might also include broader access to valuable contacts and references (social network) when needed in the exploration and exploitation activities of the new firm. 
Additionally, specific entrepreneurial experience might have been gained if the founder has had similar roles in other new ventures. This entrepreneurial experience, also defined as the "capability" to cope with the liabilities of newness [24] would be a differential element in NTBFs lead by experienced entrepreneurs. Furthermore, if the previous startup experience is in the same industry, it could provide with further legitimacy and reputation when attempting to access resources needed for the exploration and exploitation of the opportunity [26].

Thus we expect that the different dimensions of founder's human capital will share an expected positive influence on NTBF's growth.

- H1a: Founder's human capital (in years of work experience) has a positive effect on NTBF's growth.

- H1b: Founder's human capital (in number of businesses started) has a positive effect on NTBF's growth.

- H1c: Founder's human capital (in number of business started in the same industry) has a positive effect on NTBF's growth.

\section{2) Technology and marketing orientation}

If our first component of the theoretical framework is related to the expectation that founder's human capital has a positive influence on new venture growth. The following components are related to the expectation that besides the founder's human capital, there are other factors related to the actions and decisions made by entrepreneur that will also have an impact on the venture's growth. Following the concepts of "technology-push" and "demand pull" as described in innovation literature [8], we expect that in the context of a new venture the push-pull dilemma is equivalent to the strategic orientation challenge of balancing technology and market actions [27]. NTBFs start often with a single product or service, thus their choices on innovation strategy become inherently choices in the strategic orientation of the firm.

The scientific or engineering source of most technology entrepreneurship opportunities, describe a situation where investing in $R \& D$ and displaying a clear focus on the technical advantages of the new product, is aligned with the nascent identity of the firm [28]. In addition, visible outputs of the technology orientation of the firm, such as patents, provide a dual contribution to the NTBF; first, they provide much needed differential resources and specific knowledge assets; second, they are visible signs of technological capacity, rising the new firm legitimacy and reputation in the competition for attention and financial resources [29].

The demand-side view provides further clues to support this hypothesis, as we would expect potential customers for the NTBF to be sensitive to "quality signals" such as patents. Observable, and differential, technological qualities would help to establish different preferences, influencing the "willingness to pay" for that product or service [19]. Therefore, in technology markets, specific technology signals could positively influence the value creation process.
Thus we would expect that firms that develop a technological orientation would exhibit higher growth in the subsequent years.

- H2: Technology Orientation has a positive effect on NTBF's growth

Besides the seemingly natural focus on "technology-push", there is an alternative innovation strategy: "demand-pull". A demand focused firm is described to have a market strategic orientation, this would mean that this firm gives priority to learn from customers latent needs and create customer value [30]. This would mean that the NTBF development priorities would shift towards making the technological innovation useful for customers, and focus on adapting the application of the product to an identified customer need [27]. Marketing research has found support on the superior performance of firms that adopt a market orientation [31], [32], suggesting that this could actually be a driver of NTBF's growth.

Nevertheless, prior research has also suggested that market orientation could also have a negative effect, excessive focus in existing customer needs might also limit the "innovativeness" of the technology product, making it very difficult to protect in a dynamic competitive setting [27]. Overall, this could reduce the growth potential of the new entrant [33].

Overall, we suggest that positive effects of market orientation will outweigh the potential long term growth constrain. Thus, we expect that NTBFs with market orientation will still exhibit higher growth than other firms that are not observed to adopt this orientation.

- H3: Market Orientation has a positive effect on NTBF's growth.

\section{RESEARCH DESIGN}

\section{A. Method \& Data}

This research proposes to assess the influence of different factors in the growth of NTBFs. In other words, it means that we are expecting to be able to observe how those factors help to understand the growth in the early stages of a new technology-based venture. As we aim to relate variables that are part of the initial configuration of the NTBF (founder's human capital), variables that could describe a strategic orientation, with a dependent variable that can evolve across the years (NTBF's growth); we are in need of a method that captures venture changes and outcomes across time [34]. The longitudinal approach, combined with a panel data (where we can observe the changes in same individuals - or firms - across different years) offers this possibility.

We use data from the Kauffman Firm Survey (KFS) to test the above presented hypotheses. The KFS is a longitudinal panel data set (baseline in 2004 and with up to seven waves of yearly data) of new business in the US, registered on the Dun $\&$ Bradstreet (D\&B) database. It tracks up to 4,800 firms, of which a selection of them can be described as new technologybased firms. For more information on the KFS survey design and methodology, please see Robb \& Reynolds [35].

Based on Chapple et al. classification and definition [36], Technology-based firms are identified as those that operate in 
"high-technology employers" or "high-technology generators" industries, as per the R\&D activities and employees' profiles in that industry. Using the NAICS industry code of the firms, the categorization between high-technology ("employers" or "generators") or non-high technology categorization.

The final sample used in this study is of 249 new technology-based firms that reported their activity and changes from 2004 to 2007 . We selected the first four years of activity as a time-span that would offer the possibility to observe different behaviors and changes across a substantial time period [34].

The companies in the sample where in different hightechnology sub industries, the largest groups where from computer systems design and related services (24\%); computer and electronic products manufacturing (18\%); architecture, engineering and related services (13\%); custom computer programming services (11\%); machinery manufacturing $(7 \%)$; other technological sub industries $(27 \%)$.

\section{B. Measures}

\section{1) Dependent variable}

The study of NTBF's growth uses sales (revenues), employment and profits as measurement variables. Prior research has used sales growth as an indicator of the acceptance of the firm's products and services to the market [16]. Employment offers an indicator of firm growth regardless of the evolution of revenues, this measure is particularly relevant in technology intense sectors where often the revenues are not (at least on the early-stage) a clear indicator of the growth in value of the firm [37]. Last, the introduction of profit as a growth measure is related to the need to use an indicator of sustainable growth in the long term. One of the main worries in technology entrepreneurship policy is that the new firms created can sustain their activity, thus the need to achieve "profitable growth" in order to survive in the market [38], [39]. With this three different measures for the dependent variable we expect to capture the multidimensionality of NTBF's growth.

\section{2) Independent variables}

In order to define measures for the founder's human capital, we have relied in the number of work experience years (in 2004, when they start the new venture), the number of previous business started, and the number of previous business started in the same industry. These measures have also been used in previous studies as an alternative to an objective measure of the knowledge and skills of the founder [25], [40]. Instead of creating a conjoint measure for human capital, we have maintained the different separate measures in order to be able to test separately each of the sub-hypotheses proposed $(\mathrm{H} 1 \mathrm{a}$, H1b, H1c).

The measurement variables for strategic orientation (technology or market) are time-varying. This means, that we expect that some firms might exhibit a high technology or market orientation since first years, but other might actually change their orientation intensity across the different waves of data (from 2004 to 2007). Therefore, we are interested in capturing between and within effects of these variables in the growth of the new firm, building what has been described as an "hybrid model" [41]. As a result, for each of the orientations under study, we have introduced a between effects measure (the firm average orientation intensity across the different years), and a within effects (the firm deviation from its own average in each of the years). With the "between" measure, we expect to see how the difference in comparison with other firms helps to understand the differences in growth. With the "within" measure, we expect to assess whether firms that increase or decrease their orientation see changes in their growth [41]

We use the number of patents as an indicators of technology orientation. Patents have been used observed as valuable measures for technology quality of startups [29], and in this context provide an indicator of the commitment of the firm in their R\&D activities and a proxy for the willingness of the firm to be offering state-of-the-art technology to its potential customers.

In order to measure market orientation we use firm's trademarks. Recent research has shown the usefulness of trademarks to measure market innovation efforts in firms [42], [43]. A trademark represents the determination of the firm to establish a presence in the market (with a brand, logo or claim) and they are viewed as a "direct commercial link between a firm and its prospective customers" [43, p. 970]. The literature on marketing, and in particular, on branding, provides support to argue that customers feelings and perceptions on the products can be influenced by the brand [44]. Hence, trademarks registrations provide a valuable proxy to measure the market orientation of the NTBF.

\section{DATA ANALYSIS \& RESULTS}

The descriptive statistics for the dependent and independent variables used, can be seen in TABLE 1 . We have included the number of patents and trademarks as a reference, although in the statistical analysis of the models we use the firm average (avg) and deviation (dev). From the descriptive data of the sample, the average values of the three different measures for growth provide an idea of the NTBF's profile: 3.74 employees, USD 448,637 in revenues, and with profits (loses) of USD 16.981 .

We analyzed the longitudinal panel data using a random effects GLS regression. GLS models do not produce the biased estimates that using an OLS model would generate as we get repeated measurements from the same firms across the years, for similar examples using this method, please see Katila \& Chen [45] .

The different possible measures for NTBF's growth where used treated as different dependent variables, as a result we created three different models (revenues, employees, and profit). In each model we did a two-step analysis, first testing the variable of $\mathrm{H} 1$ : founder's human capital, and a second step introducing Technology (H2) and Market Orientation (H3) variables. Results are detailed in TABLE 2. 
TABLE I. DESCRIPTIVE STATISTICS

\begin{tabular}{|c|c|c|c|c|c|c|c|c|c|c|c|c|c|c|c|}
\hline & & Mean & SD & 1 & 2 & 3 & 4 & 5 & 6 & 7 & 8 & 9 & 10 & 11 & 12 \\
\hline 1 & Employees & 3.74 & 7.27 & 1.00 & & & & & & & & & & & \\
\hline 2 & Revenues (sales) & $448,637.80$ & $3,918,177.00$ & 0.16 & 1.00 & & & & & & & & & & \\
\hline 3 & Profits & $-16,982.21$ & $575,880.00$ & -0.17 & 0.07 & 1.00 & & & & & & & & & \\
\hline 4 & Work Experience (years) & 16.09 & 10.58 & -0.01 & 0.04 & 0.02 & 1.00 & & & & & & & & \\
\hline 5 & Businesses Started & 1.00 & 1.36 & -0.02 & -0.05 & -0.10 & 0.08 & 1.00 & & & & & & & \\
\hline 6 & Biz Started same Industry & 0.52 & 0.50 & 0.14 & 0.06 & -0.01 & 0.29 & -0.05 & 1.00 & & & & & & \\
\hline 7 & Trademarks (number) & 0.50 & 1.43 & 0.18 & 0.00 & -0.25 & -0.02 & 0.07 & 0.03 & 1.00 & & & & & \\
\hline 8 & (avg) Trademarks & 0.52 & 1.36 & 0.22 & 0.00 & -0.31 & 0.00 & 0.11 & 0.06 & 0.87 & 1.00 & & & & \\
\hline 9 & (dev) Trademarks & -0.02 & 0.91 & -0.03 & 0.01 & 0.03 & -0.04 & -0.05 & -0.03 & 0.51 & 0.01 & 1.00 & & & \\
\hline 10 & Patents (number) & 0.47 & 3.11 & 0.02 & 0.00 & -0.08 & 0.15 & 0.06 & 0.01 & 0.18 & 0.16 & 0.09 & 1.00 & & \\
\hline 11 & (avg) Patents & 0.46 & 1.50 & 0.12 & 0.00 & -0.20 & 0.20 & 0.15 & 0.02 & 0.31 & 0.35 & 0.01 & 0.51 & 1.00 & \\
\hline 12 & (dev) Patents & 0.01 & 2.66 & -0.03 & 0.00 & 0.00 & 0.07 & 0.00 & 0.00 & 0.05 & 0.01 & 0.10 & 0.95 & 0.10 & 1.00 \\
\hline
\end{tabular}

(avg): firm's mean, measuring between firm component

(dev): firm's mean deviation, measuring within firm componen

Overall, we observed weak response for the model that had revenues as growth's dependent variable. Meanwhile, employment $\left(\mathrm{R}^{2}: 0.10, \mathrm{p}<0.05\right)$, and profit $\left(\mathrm{R}^{2}: 0.15, \mathrm{p}<0.05\right)$, produced more positive results in our assessment of the model. Furthermore, in the employment and profit model the introduction of the Technology and Market Orientation variables had a positive effect on the overall $\mathrm{R}^{2}$ of the model.

In more detail, we follow with a description of the hypotheses results for each of the models.

\section{A. Influence on revenues as NTBF's growth variable}

In spite of the limited value of this specification, as the model produced a rather low $\mathrm{R}^{2}$ and $\mathrm{Wald} \mathrm{Chi}^{2}$, meaning that we cannot ensure that all coefficients could not be zero with a minimum acceptable probability; we can still comment that for H1c we observed a positive relationship between number of businesses started in the same industry and revenues $(449,452$; $\mathrm{p}<0.1$ ), similarly we observe that firms increasing their number of trademarks would also have generated higher revenues $(91,456 ; \mathrm{p}<0.1)$. Again, the interpretation of this results lack a reliable statistical support.

\section{B. Influence on employment as NTBF's growth variable}

The second model using number of employees as a dimension of NTBF's growth provides the opportunity to assess the validity of two of our hypotheses. Regarding H1c, we observe that there is a positive influence of founder's human capital (measured as number of previous business started in the same industry) and the growth of the number of employees $(2.4, \mathrm{p}<0.01)$. We also found statistical significance to shed some light on $\mathrm{H} 3$, observing that firms average number of trademarks in the early-stage years (2004-2007) shows a positive coefficient on the number of employees $(1.28, \mathrm{p}<0.1)$. We could not get statistical support to discuss the $\mathrm{H} 2$ on the influence of technological orientation.

\section{Influence on profits as NTBF's growth variable}

Last, using firm's profit as a measure of sustainable firm's growth, we found we can describe results for each of the hypotheses and with good support for the overall model. First, we observe different effects of founder's human capital: meanwhile $\mathrm{H} 1 \mathrm{a}$ points to a weak influence of the number of years of work experience $(2,503 ; \mathrm{p}<0.25)$, H1b shows a negative coefficient $(-24,845 ; \mathrm{p}<0.25$ - with stronger statistical support in isolated model for human capital).

For $\mathrm{H} 2$, we found limited statistical support to argue that average number of patents works as an indicator of firm profits, suggesting a rather negative influence on profits $(-26,622$; $\mathrm{p}<0.25)$.

For H3, we observed that the number of trademarks (firm's average across the years) had a negative effect in the NTBF's profits $(-92,861 ; \mathrm{p}<0.05)$.

In conclusion, we mostly found positive influence of founder's human capital on revenues and sales, although it showed to be negative in relation to profits growth. Regarding technology orientation, the weak statistical support on the models exploring revenues and sales, limit us to only propose that there seems to be a potential negative effect on the profits of the firm. Last, regarding the market orientation, it is observed to be positive on revenues (limited by the weak statistical support), and on employment; but a negative influence on profits.

\section{FINDINGS DISCUSSION \& IMPLICATIONS}

The main contribution of this study is to provide insights on the growth factors of NTBFs in their early-stages. We built on the resource-based view perspective to study the influence of the founder's human capital; we complement this perspective with the introduction of the demand-side view factors to explain the expected influence of technology and market orientation in the NTBF's growth. There are several findings.

\section{A. Findings Discussion}

First, we find that as suggested in prior research, founder's human capital is a rather complex and multidimensional variable [25]. As we have observed in the results obtained, there is an observable difference between exploring the influence of work experience (years) and looking at the number of businesses started, in particular if in the same industry. This finding offers support to recent discussion on the specific value of entrepreneurial experience [40], but in particular we offer additional information on the influence of experience. 
TABLE II. GLS REGRESSION RESULTS

\begin{tabular}{|c|c|c|c|c|c|c|c|c|c|c|c|c|c|c|c|c|}
\hline & \multicolumn{6}{|c|}{ Revenues (Sales) } & \multicolumn{5}{|c|}{ Employment } & \multicolumn{5}{|c|}{ Profit } \\
\hline & Coef. & & Robust S.E. & Coef. & & Robust S.E. & Coef. & RS.E. & Coef. & & R S.E. & Coef. & Robust S.E. & Coef. & & Robust S.E. \\
\hline Work Experience (years) & 8,869 & & 17,287 & 8,983 & & 17,818 & -0.04 & 0.04 & -0.04 & & 0.04 & $2,137 \wedge \wedge$ & 1,646 & 2,503 & $\wedge$ & 1,586 \\
\hline Businesses Started & $-167,185$ & $\wedge$ & 118,107 & $-166,690$ & $\wedge$ & 111,465 & -0.01 & 0.30 & -0.19 & & 0.32 & $-39,522 \quad * * *$ & 17,874 & $-24,845$ & $\wedge$ & 16,865 \\
\hline Biz Started same Industry & 449,452 & $*$ & 249,745 & 456,541 & $*$ & 257,775 & 2.40 & $* * * 0.89$ & 2.10 & $* * *$ & 0.81 & $-30,562$ & 56,989 & $-\quad 9,895$ & & 47,464 \\
\hline $\begin{array}{l}\text { (avg) Trademarks } \\
\text { (dev) Trademarks }\end{array}$ & & & & $\begin{array}{r}5,401 \\
91,456 \\
\end{array}$ & $*$ & $\begin{array}{l}61,786 \\
49,461 \\
\end{array}$ & & & $\begin{array}{r}1.28 \\
-0.07 \\
\end{array}$ & $*$ & $\begin{array}{l}0.68 \\
0.34 \\
\end{array}$ & & & $\begin{array}{r}-92,861 \\
6,593 \\
\end{array}$ & & $\begin{array}{l}46,584 \\
24,790 \\
\end{array}$ \\
\hline $\begin{array}{l}\text { (avg) Patents } \\
\text { (dev) Patents }\end{array}$ & & & & $\begin{array}{r}14,718 \\
7,391 \\
\end{array}$ & & $\begin{array}{l}52,016 \\
10,257 \\
\end{array}$ & & & $\begin{array}{l}0.25 \\
0.03 \\
\end{array}$ & & $\begin{array}{l}0.27 \\
0.04 \\
\end{array}$ & & & $\begin{array}{r}26,622 \\
-\quad 2,883 \\
\end{array}$ & & $\begin{array}{r}21,209 \\
3,772 \\
\end{array}$ \\
\hline constant & 558,782 & $* * *$ & 187,477 & 536,500 & $* * *$ & 186,524 & $3.39=$ & $* * * 0.80$ & 3.00 & $* * *$ & 0.75 & 24,435 & 44,626 & 51,543 & & 43,373 \\
\hline $\mathbf{n}$ & \multicolumn{3}{|c|}{249} & \multicolumn{3}{|c|}{249} & \multicolumn{2}{|r|}{249} & \multicolumn{3}{|c|}{249} & \multicolumn{2}{|l|}{249} & \multicolumn{3}{|c|}{249} \\
\hline $\begin{array}{c}\text { Wald Chi2 } \\
\text { Change in R-sq }\end{array}$ & \multicolumn{3}{|c|}{4.41} & \multicolumn{3}{|c|}{$\begin{array}{l}9.37 \\
0.00\end{array}$} & \multicolumn{2}{|c|}{$9.61 \quad * *$} & \multicolumn{3}{|c|}{\begin{tabular}{|ll}
17.6 & $* *$ \\
0.07 & \\
\end{tabular}} & \multicolumn{2}{|l|}{$7.12 *$} & \multicolumn{3}{|c|}{$\begin{array}{r}15.46 \text { ** } \\
0.13\end{array}$} \\
\hline R-sq & \multicolumn{3}{|c|}{0.01} & \multicolumn{3}{|c|}{0.01} & 0.03 & & \multicolumn{3}{|l|}{0.10} & \multicolumn{2}{|l|}{0.02} & \multicolumn{3}{|l|}{0.15} \\
\hline
\end{tabular}

Meanwhile we see that it has a positive influence on revenues and on employees growth, it has a negative influence on profits. Arguably, prior entrepreneurial experience, in particular if in the same industry, can help to contact customers, recruit employees, but still might not offer an advantage when it comes to profitable growth. Furthermore, the idea that experienced entrepreneurs might suffer from pathdependency [46], trying to repeat the same processes or reasoning that worked in the past into a new situation, might actually have negative effect on the NTBF's performance measured in profits.

Second, our results provide empirical evidence on the technology-push vs. demand-pull adaptation in the NTBF's context. The innovation orientation decisions made in the early-stages of the new firm are expected to have a strategic significance for the firm growth and overall development. The demand-side view provides an explanation on how those strategic moves might produce the needed signals to activate customer demand [19]. While initially surprising, the observation that firms with higher number of average patents and trademarks would have lower profits in the observed period, would be an example of the limited value of patents and trademarks as new firm's resources. Suggesting that if any, their influence is generated through other mechanisms that were not captured in this study. Although statistically weak, the observation that market orientation (positive change in the number of trademarks (dev)) could have a positive influence on the revenues, opens the possibility that, as observed in other types of firms [43], developing a market orientation in the early stages could have a positive effect on the revenues development.

Third, the differences observed in the different models, show that firm growth dimensions exhibit a rather different behavior. Thus, we contribute to the ongoing discussion on the types and modes of growth [39], by exploring the influence of human capital, technology and market orientation in different dimensions of growth. The discussion on the growth measures is relevant in the context of technology entrepreneurship, as NTBFs do often follow different patterns in growth, and can create value (p.e. through a company sale) for their founders and investors without actually producing revenues (as in the case of some internet or software development startups). Thus, we have taken advantage of the panel data to explore different dimensions of venture growth as a dependent variable [34].

\section{B. Implications}

The implications of this study and its findings are two folded. From the academic research perspective, we have advanced in the understanding of founder's human capital impact on the new venture growth. In addition we have also introduced the strategic orientation concept (technology or market orientation) to study their role as factors in the earlystage success. Overall our research contributes to the development of the demand-side view by introducing empirical evidences on the value creation process that we can observe in some technology entrepreneurship contexts.

The findings have also practical implications for entrepreneurship managers, investors and stakeholders. The observation of the limited and sometimes even negative influence of some types of human capital, and of often coveted resources such as patents, generates support for further discussion on their function as credible signals of future success. In addition, we can argue that the absence of IP resources did not seem to affect the growth in any of the dimensions of the new firms, suggesting that still most of the outcomes are dependent on elements that go beyond the new venture's initial resources.

\section{Limitations and further research}

There are limitations in the study, as well as opportunities for further research. First, the heterogeneity of firms classified as high technology or technology-based firms, suggests that we would get a better understanding from a more granular analysis. Second, the findings and discussions could be refined and extended if control variables for firm size and initial financial resources where introduced. Third, we have not captured changes neither patterns in the technology or market orientation, an event based analysis on the changes in orientation across the different waves could uncover different profiles of startups growth. And fourth, we could explore alternative measures to the different constructs under study, 
aiming to confirm this initial findings and make plausible further generalization.

\section{CONCLUSIONS}

Technology entrepreneurship remains as a little understood phenomenon despite the growing interest in promoting successful new technology-based firms. While much of the research focus has been on exploring the influence of resources, we have little understanding on the impact of actions and decisions such as setting, and changing, the innovation orientation of the firm.

In this study we have advanced in our understanding of resources such as the founder's human capital, and on the dual path of action between focusing on technological or market development.

We have contributed to the development of empirical evidence in the study of new technology-based firm's growth, as well as to the extension of the literature on this specific domain.

\section{ACKNOWLEDGMENTS}

The authors wish to thank the Kauffman Foundation for providing access to the NORC Enclave for the Kauffman Firm Survey. Any opinions, findings, and conclusions or recommendations expressed in this material are those of the authors and do not necessarily reflects the views of the Ewing Marion Kauffman Foundation.

\section{REFERENCES}

[1] S. A. Shane, "Why encouraging more people to become entrepreneurs is bad public policy," Small Bus. Econ., vol. 33, no. 2, pp. 141-149, Jun. 2009.

[2] J. Lerner, "The future of public efforts to boost entrepreneurship and venture capital," Small Bus. Econ., vol. 35, no. 3, pp. 255-264, Jul. 2010

[3] T. Bailetti, "Technology Entrepreneurship : Overview, Definition, and Distinctive Aspects," Technol. Innov. Manag. Rev., no. February, pp. 5-12, 2012.

[4] F. Giones, Z. Zhou, F. Miralles, and B. Katzy, "From Ideas to Opportunities: Exploring the Construction of Technology-Based Entrepreneurial Opportunities," Technol. Innov. Manag. Rev., no. June, pp. 13-20, 2013.

[5] A. Brem and J. Borchardt, "Technology entrepreneurship, innovation and intrapreneurship - managing entrepreneurial activities in technologyintensive environments," in Handbook Of Research On TechnoEntrepreneurship, 2nd ed., F. Thérin, Ed. Cheltenham, UK.: Edward Elgar, 2014, pp. 17-38.

[6] R. Brown and C. Mason, "Inside the high-tech black box: A critique of technology entrepreneurship policy,” Technovation, Aug. 2014.

[7] D. H. Hsu, "Technology-based Entrepreneurship," in Handbook of Technology and Innovation Management, S. Shane, Ed. Hoboken, NJ: Wiley, 2008, pp. 367-388.

[8] A. Brem and K.-I. Voigt, "Integration of market pull and technology push in the corporate front end and innovation management-Insights from the German software industry," Technovation, vol. 29, no. 5, pp. 351-367, May 2009.

[9] G. P. West and T. W. Noel, "The impact of knowledge resources on new venture performance," J. Small Bus. Manag., vol. 47, no. 1, pp. 1-22, Jan. 2009.

[10] F. Strehle, B. R. Katzy, and T. Davila, "Learning capabilities and the growth of technology-based new ventures," International Journal of Technology Management, vol. 52, no. 1/2. p. 26, 2010.

[11] Y. Choi and D. Shepherd, "Entrepreneurs' decisions to exploit opportunities," J. Manage., pp. 1-38, 2004.

[12] R. L. Priem, "A consumer perspective on value creation," Acad. Manag. Rev., vol. 32, no. 1, pp. 219-235, Jan. 2007.

[13] M. S. Wood and W. McKinley, "The production of entrepreneurial opportunity: a constructivist perspective," Strateg. Entrep. J., vol. 4, no. 1, pp. 66-84, Mar. 2010.

[14]Z. Zhou, "Technology entrepreneurship - A process framework," Leiden University, 2013.

[15]F. Giones and F. Miralles, "Do Actions Matter More than Resources? A Signalling Theory Perspective on the Technology Entrepreneurship Process," Technol. Innov. Manag. Rev., no. March, pp. 39-45, 2015

[16] J. Brinckmann, S. Salomo, and H. G. Gemuenden, "Financial Management Competence of Founding Teams and Growth of New TechnologyBased Firms," Entrep. Theory Pract., vol. 35, no. 2, pp. 217-243, Mar. 2011.

[17] B. Wernerfelt, "The resource-based view of the firm: Ten years after," Strateg. Manag. J., vol. 16, no. 6, pp. 171-174, 1995.

[18] R. L. Priem and J. Butler, "Is the resource-based 'view' a useful perspective for strategic management research?," Acad. Manag. Rev., vol. 26 , no. 1 , pp. 22-40, 2001.

[19] R. L. Priem, S. Li, and J. C. Carr, "Insights and New Directions from Demand-Side Approaches to Technology Innovation, Entrepreneurship, and Strategic Management Research," J. Manage., vol. 38, no. 1, pp. 346-374, Dec. 2011.

[20]F. Giones, Z. Zhou, F. Miralles, and B. Katzy, "A Constructivist Approach for Technology-based Entrepreneurship," in Proceedings of the XXIII ISPIM Conference, 2012.

[21] A. C. Godley, "Entrepreneurial opportunities, implicit contracts, and market making for complex consumer goods," Strateg. Entrep. J. vol. 7, no. 4, pp. 273-287, Nov. 2013.

[22] S. A. Shane, "Prior knowledge and the discovery of entrepreneurial opportunities," Organ. Sci., vol. 25, no. 1, pp. 448-469, 2000.

[23] D. A. Shepherd, E. J. Douglas, and M. Shanley, "New venture survival," $J$. Bus. Ventur., vol. 15, no. 5-6, pp. 393-410, Sep. 2000.

[24] D. Politis, "Does prior start-up experience matter for entrepreneurs' learning?: A comparison between novice and habitual entrepreneurs," J. Small Bus. Enterp. Dev., vol. 15, no. 3, pp. 472489, 2008. 
[25] M. G. Colombo and L. Grilli, "Founders' human capital and the growth of new technology-based firms: A competence-based view," Res. Policy, vol. 34, no. 6, pp. 795-816, Aug. 2005.

[26] S. L. Newbert and E. T. Tornikoski, "Resource Acquisition in the Emergence Phase: Considering the Effects of Embeddedness and Resource Dependence," Entrep. Theory Pract., p. no-no, May 2011.

[27] K. Zhou, C. Yim, and D. Tse, "The effects of strategic orientations on technology-and market-based breakthrough innovations," J. Mark., vol. 69 , no. 2, pp. 42-60, 2005.

[28] I. Drori, B. Honig, and Z. Sheaffer, "The life cycle of an internet firm: Scripts, legitimacy, and identity," Entrep. Theory Pract., vol. 33, no. 3, pp. 715-738, 2009.

[29] D. H. Hsu and R. H. Ziedonis, "Resources as dual sources of advantage: Implications for valuing entrepreneurial-firm patents," Strateg. Manag. J., vol. 34, no. 7, pp. 761-781, Jul. 2013.

[30] J. W. Webb, R. D. Ireland, M. a. Hitt, G. M. Kistruck, and L. Tihanyi, "Where is the opportunity without the customer? An integration of marketing activities, the entrepreneurship process, and institutional theory," J. Acad. Mark. Sci., vol. 39, no. 4, pp. 537-554, Nov. 2010

[31] K. Atuahene-Gima and A. Ko, "An Empirical Investigation of the Effect of Market Orientation and Entrepreneurship Orientation Alignment on Product Innovation," Organ. Sci., vol. 12, no. 1, pp. 54-74, Feb. 2001

[32] G. T. M. Hult, D. J. Ketchen, and S. F. Slater, "Market orientation and performance: an integration of disparate approaches," Strateg. Manag. J., vol. 26, no. 12, pp. 1173-1181, Dec. 2005.

[33] J. S. Gans and S. Stern, "The product market and the market for 'ideas' commercialization strategies for technology entrepreneurs," Res. Policy, vol. 32, no. 2, pp. 333-350, Feb. 2003.

[34] P. Davidsson and S. R. Gordon, "Panel studies of new venture creation: a methods-focused review and suggestions for future research," Small Bus. Econ., vol. 39, no. 4, pp. 853-876, Apr. 2011.

[35] A. Robb and P. D. Reynolds, "PSED II and the Kauffman Firm Survey," in New Firm Creation in the United States, R. T. Curtin and P. D. Reynolds, Eds. New York, NY: Springer New York, 2009.

[36] K. Chapple, A. Markusen, G. Schrock, D. Yamamoto, and P. Yu “Gauging Metropolitan 'High-Tech' and 'I-Tech' Activity," Econ. Dev. Q., vol. 18, no. 1, pp. 10-29, Feb. 2004.

[37] A. Davila, G. Foster, and M. Gupta, "Venture capital financing and the growth of startup firms," J. Bus. Ventur., vol. 18, no. 6, pp. 689-708, Nov. 2003.

[38] P. Steffens, P. Davidsson, and J. Fitzsimmons, "Performance Configurations Over Time: Implications for Growth- and ProfitOriented Strategies," Entrep. Theory Pract., vol. 33, no. 1, pp. 125 148, Jan. 2009.

[39] F. Bertoni, M. G. Colombo, and L. Grilli, "Venture capital investor type and the growth mode of new technology-based firms," Small Bus. Econ., Nov. 2011

[40] D. Dimov, "Nascent Entrepreneurs and Venture Emergence: Opportunity Confidence, Human Capital, and Early Planning," J. Manag. Stud., vol. 47 , no. 6 , pp. $1123-1153$, Sep. 2010.
[41] R. Schunck, "Within and between estimates in random-effects models: Advantages and drawbacks of correlated random effects and hybrid models," Stata J., 2013

[42] S. Mendonça, T. S. Pereira, and M. M. Godinho, "Trademarks as an indicator of innovation and industrial change," Res. Policy, vol. 33, no. 9, pp. 1385-1404, Nov. 2004.

[43] P. G. Sandner and J. Block, "The market value of R\&D, patents, and trademarks," Res. Policy, vol. 40, no. 7, pp. 969-985, Sep. 2011.

[44] L. L. Berry, "Cultivating Service Brand Equity," Journal of the Academy of Marketing Science, vol. 28. pp. 128-137, 2000.

[45] R. Katila and E. L. Chen, "Effects of Search Timing on Innovation: The Value of Not Being in Sync with Rivals," Administrative Science Quarterly. 2008.

[46] R. Garud, A. Kumaraswamy, and P. Karnøe, "Path Dependence or Path Creation?,” J. Manag. Stud., vol. 47, no. 4, pp. 760-774, Jun. 2010 